\title{
Hairy roots of Dracocephalum moldavica: rosmarinic acid content and antioxidant potential
}

\author{
Izabela Weremczuk-Jeżyna • Izabela Grzegorczyk-Karolak • \\ Barbara Frydrych · Aleksandra Królicka • \\ Halina Wysokińska
}

Received: 6 July 2012/Revised: 15 February 2013/Accepted: 19 February 2013/Published online: 17 March 2013

(C) The Author(s) 2013. This article is published with open access at Springerlink.com

\begin{abstract}
Hairy roots of Dracocephalum moldavica L. were induced using Agrobacterium rhizogenes strain A4. Transformed roots were obtained from shoot explants with low transformation frequency of up to $3 \%$. The effects of different liquid media: Murashige and Skoog (MS), Gamborg et al. (B5) and Woody Plant (WP) with full- and half-strength $(1 / 2 \mathrm{MS}, 1 / 2 \mathrm{~B} 5,1 / 2 \mathrm{WP})$, on biomass accumulation and rosmarinic acid (RA) content were investigated. The hairy roots were cultured in photoperiod $(16 \mathrm{~h} \mathrm{light} / 8 \mathrm{~h}$ dark $)$ and darkness. Biomass of $\mathrm{D} . \mathrm{mol}$ davica hairy roots was the highest $\left(7.23 \mathrm{~g} \mathrm{flask}^{-1}\right.$ of fresh weight and $0.89 \mathrm{~g} \mathrm{flask}^{-1}$ of dry weight) in the cultures grown in WP medium under periodic light. Ultra performance liquid chromatography analysis revealed the highest RA content ( $78 \mathrm{mg} \mathrm{g}^{-1}$ dry wt) in roots cultured in $1 / 2 \mathrm{~B} 5$ medium under photoperiod conditions. It was about tenfold higher compared to roots of field-grown mother plants. Antioxidant activities and total phenolic contents of methanolic extracts of $D$. moldavica hairy roots cultured in
\end{abstract}

Communicated by K.-Y. Paek.

I. Weremczuk-Jeżyna ( $₫)$ · I. Grzegorczyk-Karolak ·

H. Wysokińska

Department of Biology and Pharmaceutical Botany,

Medical University of Łódź, Muszyńskiego1,

90-151 Lodz, Poland

e-mail: izabela.weremczuk-jezyna@umed.pl;

izabela.weremczuk-jezyna@umed.lodz.pl

B. Frydrych

Department of Toxicology, Medical University of Łódź,

Muszyńskiego1, 90-151 Lodz, Poland

A. Królicka

Department of Biotechnology, University of Gdańsk

and Medical University of Gdańsk,

Kładki 24, 80-822 Gdańsk, Poland
$1 / 2 \mathrm{~B} 5$ and WP media under photoperiod and darkness and roots of field grown plants were compared. All extracts were investigated using 1,1-diphenyl-2-picrylhydrazyl (DPPH) scavenging and phosphomolybdenum reduction assays. Total phenolic contents were estimated by the FolinCiocalteu method. The methanolic extract of $D$. moldavica hairy roots grown in $1 / 2 \mathrm{~B} 5$ medium under photoperiod possessed the strongest effects on reducing Mo and DPPH radical scavenging. The activities were significantly higher $(p \leq 0.05)$ than those of methanolic extract of roots of intact plants grown in the field. The most active methanolic extract of hairy roots was characterized by the highest level of rosmarinic acid and total content of phenolic compounds.

Keywords Hairy roots $\cdot$ Agrobacterium rhizogenes . Rosmarinic acid $\cdot$ Antioxidant activity

\section{Introduction}

Dracocephalum moldavica L., commonly known in Iran as "badarshoo", is a annual aromatic plant belonging to the Lamiaceae family. This plant is native to Siberia and Central Asia and has been cultivated in eastern and central Europe. D. moldavica is frequently used as a food ingredient and a carditonic agent, as well as for the treatment of stomach and liver disorders, and headache (Dastmalchi et al. 2007a, b). There are also reports on anti-Helicobacter pylori activity (Ghanndi et al. 2004) as well as sedative, analgesic and wound-healing properties of dragonhead extracts (Sultan et al. 2008). Crude extracts of the aerial parts of D. moldavica contain a number of constituents with well-documented biological activity, including flavonoids (luteolin, 7-O-glucoside luteolin, apigenin), iridoids, essential oil components, ursolic and oleanolic acids as 
well as hydroxycinnamic acids with caffeic, ferulic and rosmarinic acids (Kakasy et al. 2006; Popova et al. 2008; Sultan et al. 2008).

Rosmarinic acid (RA) is an ester of caffeic acid and 3,4-dihydroxyphenyllactate. RA has applications as a food preventive and in medicine due to its antioxidant, antimicrobial, antiinflammatory and antiviral properties (Bais et al. 2002; Ly et al. 2006; Park et al. 2008). There are reports on RA activity against Herpes simplex virus 1 (HSV-1) (SanchezMedina et al. 2007), Human immunodeficiency virus (HIV-1) (Tewtrakul et al. 2003) and Helicobacter pylori (Chun et al. 2005). Considering the importance of the compound for pharmaceutical, cosmetic and food industries, numerous investigations were carried out to obtain RA from wild-grown plants and from cell, callus and organ cultures (Janicsàk et al. 1999; Bauer et al. 2004; Georgiev et al. 2006; Park et al. 2008). Biotechnological methods based on in vitro plant cultures are considered to provide the possibility of producing standardized material independent of environmental factors.

Although RA has been extracted from D. moldavica plants (Povilaitytè et al. 2001) there is no information on this species with respect to in vitro production of the phenolic compound. This present research was devoted to investigate hairy root culture of $D$. moldavica for the production of RA. These root cultures obtained after infection of plant tissues with soil bacteria are characterized by fast, auxin-independent growth, high level of secondary metabolites and better genetic and biochemical stability compared to other in vitro culture systems (Giri and Narasu 2000). Herein, we describe the establishment of D. moldavica hairy root culture. To our knowledge, this is the first report on the genetic transformation of this plant species. The hairy root culture was optimized for growth and RA content by monitoring the effect of media composition and physical culture conditions (dark and lightcontaining photoperiod) and compared to RA content in roots of intact plants of $D$. moldavica growing in the field. The comparative analysis of antioxidant activity of methanolic extracts from transformed and natural roots was also presented. For this purpose, two assays (DPPH - free radical scavenging activity and reduction of transition metal ions by phosphomolybdenum complex) were used. Total phenolic compound contents in methanolic extracts of hairy roots and roots of intact plants were determined to find correlations with antioxidant properties.

\section{Materials and methods}

Plant material and bacterial strain

Seeds of D. moldavica were purchased from the Botanical Garden of Lublin (Poland). The seeds were surface sterilized with $2 \%$ sodium hypochlorite solution for $2 \mathrm{~min}$. After rinsing with sterile distilled water, the seeds were germinated in the dark at $26{ }^{\circ} \mathrm{C}$ on MS (Murashige and Skoog 1962) agar (0.7\%) medium supplemented with $0.02 \mathrm{mg} \mathrm{L}^{-1}$ kinetin and $1.0 \mathrm{mg} \mathrm{L}^{-1}$ gibberellic acid. After germination, the seedlings were transferred into light conditions (16 h light/8 h dark; cool fluorescent lamps; $\left.40 \mu \mathrm{m} \mathrm{m}^{-2} \mathrm{~s}^{-1}\right)$. The shoot tips (0.3-0.5 $\mathrm{cm}$ long) excised from 4-week-old seedlings were placed on MS agar medium containing $0.1 \mathrm{mg} \mathrm{L}^{-1}$ indole-3-acetic-acid (IAA) and $0.2 \mathrm{mg} \mathrm{L}^{-1}$ benzylaminopurine (BAP) for shoot multiplication. After 4 weeks, the multiple shoots were transferred individually into MS medium without growth regulators for elongation.

Agrobacterium rhizogenes strain A4 harboring agropine-type plasmid $\mathrm{pR}_{\mathrm{i}} \mathrm{A} 4$ cultivated in the dark on $\mathrm{YMB}$ agar medium (Vervliet et al. 1975) at $26^{\circ} \mathrm{C}$ for $48 \mathrm{~h}$ was used for transformation.

Induction and culture of hairy roots

Four-week-old axenic shoots (2 cm long) and leaves $(0.5 \mathrm{~cm})$ excised from the shoots were used as explants for Agrobacterium-mediated transformation. The explants were wounded with a sterile needle immersed in the bacterial culture. The shoots were wounded at internodes. Leaves were inoculated in the petiole end closest to the lamina. Control explants (shoots and leaves) were wounded identically with a sterile needle. 80-100 each of two type explants were inoculated and the experiment was repeated three times. The inoculated and control explants were incubated in the dark at $26{ }^{\circ} \mathrm{C}$ on MS agar medium without growth regulators. After 3 weeks, the roots formed at wounded sites of the infected shoots were cut off and transferred individually into $100 \mathrm{~mL}$ Erlenmeyer flasks containing $30 \mathrm{~mL}$ of half-strength B5 liquid medium (1/2B5) (Gamborg et al. 1968) with ampicillin $\left(500 \mathrm{mg} \mathrm{L}^{-1}\right)$ for the elimination of bacteria. The cultures were maintained in the dark on a rotary shaker at $100 \mathrm{rpm}$. After fifth subcultures (1 week each), the concentration of ampicillin was reduced to $250 \mathrm{mg} \mathrm{L}^{-1}$. After the successive fifth passages, ampicillin was eliminated from the medium and axenic root cultures were obtained. One hairy root line, which showed sufficient growth in $1 / 2$ B5 liquid medium, was chosen for further investigations.

PCR analysis

DNA from hairy roots and untransformed roots of D. moldavica were isolated using the method described by Bekesiova et al. (1999). PCR was performed using specific primers. The sequence of primers used to amplify rolB gene was: 5'-GCT CTT GCA GTG CTA GAT TT-3'; 
5'-GAA GGT GCA AGC TAC CTC TC-3' and rolC gene 5'-CTC CTG ACA TCA AAC TCG TC-3'; 5'-TGC TTC GAG TTA TGG GTA CA- $3^{\prime}$. Each PCR contained standard PCR buffer (Promega Co., Madison), $2 \mathrm{mM} \mathrm{MgCl}_{2}$, $0.2 \mathrm{mM}$ dNTP (Gibco BRL), 8 pmol of each primer and 75-100 ng of the target DNA (final volume $50 \mu \mathrm{l}$ ). Amplification conditions were as follows: 35 cycles, initial denaturation at $94{ }^{\circ} \mathrm{C}$ for $3 \mathrm{~min}$, denaturation at $94{ }^{\circ} \mathrm{C}$ for $1 \mathrm{~min}$, primer annealing at $53.5^{\circ} \mathrm{C}(1 \mathrm{~min})$, and elongation at $72{ }^{\circ} \mathrm{C}$ ( $\left.1 \mathrm{~min}\right)$, followed by final elongation for $6 \mathrm{~min}$. The amplified sequences were separated by electrophoresis in $1.2 \%$ agarose gel in TBE buffer. The gel was stained with ethidium bromide and observed under UV light. In order to confirm that the examined hairy roots were truly transformed PCR was performed using virG gene (gene present in Ri plasmid but beyond the transferred T-DNA). The sequence of primers used to amplify virG gene were 5'-ACT GAA TAT CAG GCA ACG CC-3' and 5'-GCG TCA AAG AAA TAG CCA GC-3'. Amplification conditions in the case of virG gene were as follows: 35 cycles, initial denaturation at $94{ }^{\circ} \mathrm{C}(3 \mathrm{~min})$, denaturation at $94{ }^{\circ} \mathrm{C}$ (1 min), primer annealing at $54{ }^{\circ} \mathrm{C}(1 \mathrm{~min})$, and elongation at $72{ }^{\circ} \mathrm{C}$ for $1 \mathrm{~min}$, followed by final elongation for $6 \mathrm{~min}$. The amplified fragments were separated by electrophoresis in $1.2 \%$ agarose gel in TBE buffer. The gel was stained with ethidium bromide and observed under UV light.

\section{Optimization of growth medium}

After the 10th subculture, hairy roots $(0.2-0.3 \mathrm{~g}$ fresh weight) were transferred into $300 \mathrm{~mL}$ Erlenmeyer flasks containing $80 \mathrm{~mL}$ of liquid media: MS, WP (Lloyd and Mc Cown 1981) or B5 with full and half-strength macro- and micro-salt concentrations. All the media contained $3 \%$ sucrose. The $\mathrm{pH}$ of the media was adjusted to 5.6-5.9. The media were sterilized at the pressure of $1.06 \mathrm{~kg} \mathrm{~cm}^{-2}$ at $121{ }^{\circ} \mathrm{C}$ in an autoclave for $17 \mathrm{~min}$.

The cultures were maintained in the darkness or under a photoperiod ( $16 \mathrm{~h} / 8 \mathrm{~h}$ light/dark) with a light intensity of $40 \mu \mathrm{m} \mathrm{m}^{-2} \mathrm{~s}^{-1}$, on a rotary shaker at $100 \mathrm{rpm}$. Subcultures were carried out every 5 weeks. Then, hairy roots were harvested and their growth was measured in terms of fresh and dry weights. Three flasks were used for each medium type and culture conditions (photoperiod/darkness) and the experiments were performed in triplicate. Fresh and dry weights were expressed as $\mathrm{mg} \mathrm{flask}^{-1}$.

Roots from in vivo source

Dracocephalum moldavica plants derived from the same seeds as in vitro cultures and cultivated for 6 months in the experimental field of the Department of Pharmacognosy at the Medical University of Lodz were harvested, washed with water and used for the extraction of RA. The roots were served for comparison of RA content in untransformed and transformed roots of $D$. moldavica.

\section{Extraction and determination of RA}

Lyophilized and powdered plant materials (150 mg) (35-day-old transformed roots and roots of 6-month-old intact plants grown in the field) were extracted three times with $70 \% \mathrm{MeOH}(25 \mathrm{~mL})$ for $10 \mathrm{~min}$ at room temperature using ultrasonic bath (Janicsàk et al. 1999). After filtration, the extracts were combined and evaporated to dryness under reduced pressure. The residue was dissolved in methanol $(10 \mathrm{~mL}) .1 \mathrm{~mL}$ of methanolic extract was centrifuged at $18,000 \mathrm{rpm}$ for $3 \mathrm{~min}$. The supernatant was analyzed by ultra performance liquid chromatography (UPLC).

\section{UPLC analysis of RA}

Analysis was performed using an Acquity Ultra Performance Liquid Chromatograph (Waters) equipped with a photodiode array, a UV-visible detector and an autoinjector, according to the method described by Lamien-Meda et al. (2010). Separation was performed on a Shield RP C18-column $(2.1 \times 100 \mathrm{~mm}, 1.7 \mu \mathrm{m}$ pore size $)$ at a column temperature of $35^{\circ} \mathrm{C}$. The solvent gradient used in this study was formed with solvent $\mathrm{A}$ (1\% acetic acid:acetonitrile 85:15 v/v) and solvent B (methanol). The following gradient system was used: 0-14.6 min $90 \%$ solvent A; 14.6-16.6 min $100 \%$ solvent B, 16.6-17 min $90 \%$ solvent $\mathrm{B}$. The flow rate was $0.43 \mathrm{~mL} \mathrm{~min}^{-1}$. The samples were detected at $360 \mathrm{~nm}$. Identification of RA was done by comparing its retention time with that of the standard compound. The retention time for authentic RA $\left(\right.$ ChromaDex $^{\text {TM }}$ ) was 3.8 min. RA concentration was estimated by the interpolation of the peak area with calibration curve constructed for the authentic compound over the range of $5-200 \mu \mathrm{g} \mathrm{mL}^{-1}$. The linearity of the calibration curve was verified by the correlation coefficient $\left(r^{2}=0.9994\right)$. The experiment for producing RA from hairy root cultures and untransformed roots was repeated three times with three replicates for each medium and culture conditions (photoperiod or darkness). RA contents of the analyzed samples were expressed as milligram per gram of dry weight.

Liquid chromatography-mass spectrometry (LC-MS/MS)

LC-MS/MS was carried out using API LC/MS/MS system (Applera, USA) with electrospray ionization (ESI) source equipped with Dionex (Germany) HPLC system. The HPLC 
parameters were as described above. Detection was performed in negative ion modes with condition set as follows: drying gas $\left(\mathrm{N}_{2}\right) 11.0 \mathrm{~L} \mathrm{~min}^{-1}$, temperature $350{ }^{\circ} \mathrm{C}$, nitrogen nebulizer pressure $40 \mathrm{psi}$, capillary voltage $4.5 \mathrm{~kW}$, a detector gain of $1,600 \mathrm{~V}$, fragmentation voltage $90 \mathrm{~V}$ and full scan range from 100 to $900 \mathrm{~m} / \mathrm{z}$.

\section{Antioxidant assays}

Preparation of extracts

Lyophilized and powdered plant materials $(1 \mathrm{~g})$ were separately extracted with $70 \%$ methanol $(150 \mathrm{~mL})$. The extraction procedure was the same as that described above.

Total phenolic content

Total phenolic content was estimated using the colorimetric method based on Folin-Ciocalteu reagent, as described by Singlenton et al. (1965). A $400 \mu \mathrm{L}$ of each extract was added to the test-tubes containing $2.0 \mathrm{~mL}$ of Folin-Ciocalteu reagent and $1.6 \mathrm{~mL}$ of $7.5 \%$ sodium carbonate. The absorbance at $765 \mathrm{~nm}$ was measured after $30 \mathrm{~min}$ of incubation at room temperature. Quantification was done with respect to the standard calibration curve of gallic acid. The results were expressed as gallic acid $\mathrm{mg}$ equivalents (GAE) per gram of dry extract.

\section{Phosphomolybdenum reduction}

The method of Prieto et al. (1999) was used to assay the reducing power of $D$. moldavica root extracts. $0.4 \mathrm{~mL}$ of each extract tested $\left(100 \mu \mathrm{g} \mathrm{mL}^{-1}\right)$ was mixed with the reagent solution $(1.2 \mathrm{~mL})$ containing ammonium molybdate $(12 \mathrm{mM})$, sodium phosphate $(84 \mathrm{mM})$ and sulfuric acid $(1.8 \mathrm{M})$ in distilled water. The tubes with the reaction mixture were incubated in a water bath shaker at $90{ }^{\circ} \mathrm{C}$ for $90 \mathrm{~min}$. After cooling at room temperature, the absorbance (spectrophotometer Beijing Reyleigh, Corp. China) of the green phosphomolybdenum complex was measured at $695 \mathrm{~nm}$ against a blank containing $0.4 \mathrm{~mL}$ of methanol mixed with $1.2 \mathrm{~mL}$ reagent solution. The reducing capacity of extract was calculated using the equation: Abs final $=\mathrm{Abs}$ sample - Abs blank - Abs extracts. Butylated hydroxytoluene (BHT) and $\alpha$-tocopherol were used as standards. The results were expressed as ascorbic acid equivalents per gram of dry extract. The assay was carried out in triplicate.

DPPH radical scavenging

1,1-Diphenyl-2-picrylhydrazyl (DPPH) free radical scavenging activity was determined using the method described by Brand-Williams et al. (1995). Methanolic extracts at different concentrations $(2.0,20.0,100.0,200.0,500.0$ and $1,000.0 \mu \mathrm{g} \mathrm{mL}^{-1}$ ) were mixed with the same volume of $0.2 \mathrm{mM}$ methanolic solution of DPPH (from SigmaAldrich). After $30 \mathrm{~min}$ incubation at room temperature, the absorbance was recorded at $517 \mathrm{~nm}$ using a UV/VIS spectrophotometer. Free radical scavenging capacity was calculated as follows: \% scavenging $=100-($ Abs sample - Abs control)/Abs DPPH $\times 100 \%$, where Abs sample is the absorbance of the sample without DPPH. BHT and $\alpha$-tocopherol solution were used as standards. The antiradical activity was expressed as $\mathrm{EC}_{50}$ defined as the concentration of a sample $\left(\mu \mathrm{g} \mathrm{mL}^{-1}\right)$ at which $50 \%$ of maximum scavenging activity was recorded. The assay was carried out in triplicate.

Statistical analysis

All results were calculated as mean \pm standard error. The means were tested for statistical significance of differences by the Mann-Whitney $U$ test at a $5 \%$ probability level (Statistica 5.0, Statsoft, Poland). $\mathrm{EC}_{50}$ and the correlation coefficients $\left(r^{2}\right)$ between the antioxidant assay and the total phenolic content or RA content were calculated using MSExel software.

\section{Results and discussion}

In the present study, we first established hairy roots from 4-week-old D. moldavica axenic shoots infected with $A$. rhizogenes strain A4 and then evaluated the ability of the selected root line to produce RA. Although approximately 300 of shoot explants were used for the transformation, only nine of them responded forming a single root without lateral branching at the wound site within 3 weeks of culture on hormone-free MS medium. Longer cultivation period did not improve the results. There was no response in excised leaves infected with A. rhizogenes even after 6 weeks. Roots did not also develop on uninfected control explants. The roots excised from inoculated shoots were transferred into hormone-free half-strength B5 (1/2B5) liquid medium with ampicillin initially $500 \mathrm{mg} \mathrm{L}^{-1}$, which was gradually reduced during subsequent subcultures. Axenic root cultures were obtained after 10 subcultures. Among three root lines, one which showed fast growth in $1 / 2 \mathrm{~B} 5$ medium and produced more lateral roots was used for this investigation. The confirmation of transformed nature of the roots was made by PCR method. Two fragments with lengths of 423 and 626 bp corresponding to $r o l \mathrm{~B}$ and rolC genes, respectively, were detected in hairy root culture but not in untransformed roots, obtained from intact plants of D. moldavica. PCR analysis using primers for 
virG gene detected no bans corresponding to virG from hairy roots and roots of intact plants. It shows the absence of contamination of the roots by A. rhizogenes.

The effect of various culture media containing $3 \%$ sucrose on growth of $D$. moldavica hairy roots and RA content was examined. The media tested were: B5, MS, and WP with full and half-strength $(1 / 2 \mathrm{~B} 5,1 / 2 \mathrm{MS}$ and $1 / 2 \mathrm{WP})$ content of macro- and micro-nutrients. The cultures were grown both in darkness and under photoperiod (16 h light/ $8 \mathrm{~h}$ dark). Preliminary study showed that in all tested media, the maximum accumulation of biomass was observed after 5 weeks of growth. Therefore, a growth period of 35 days was chosen as optimum in all experiments.

The growth of hairy roots of $D$. moldavica was slightly affected by physical culture conditions (photoperiod or darkness) (Table 1). The effect was most evident for roots growing in WP medium with full concentration of nutrients. In this case, the fresh and dry weights of hairy roots cultured in darkness were over $30 \%$ lower than those achieved for roots growing under periodic light. In comparison with roots grown in other tested media, hairy roots cultured in WP medium in the presence of light showed the highest accumulation of biomass (Table 1). After a culture of 35 days, their fresh weight increased above 23 times from $0.31 \mathrm{~g} \mathrm{flask}^{-1}$ to $7.23 \mathrm{~g} \mathrm{flask}^{-1}$ ( $80 \mathrm{~mL}$ medium). Dry weight reached $0.89 \mathrm{~g} \mathrm{flask}^{-1}$, i.e. 18 -fold increase over the initial inoculum. The lowest biomass of hairy roots was observed in MS medium (Table 1). Most investigations in the literature have suggested that the concentration of nitrogen $\left(39.5 \mathrm{mM} \mathrm{NO}_{3}{ }^{-}\right.$and $20.5 \mathrm{mM}$ $\mathrm{NH}_{4}{ }^{+}$), especially of ammonium, in MS medium is too high for the growth of root cultures (Bensaddek et al. 2001; $\mathrm{Wu}$ et al. 2006). Danesh et al. (2006) have reported that high amount of ammonium in full-strength MS medium caused a rapid drop in the $\mathrm{pH}$ of the culture medium, thus reducing the growth of carrot roots. Another possible explanation is that ammonium is very diffusive and it easily accumulated into the tissues. At high concentration, only a small part of the ions can be metabolized and the excess has inhibitory effect on the cell metabolism (Richter, 1993). Probably, also in the present study, the concentration of nitrogen in medium may influence on D. moldavica transformed roots growth. Our results obtained in $1 / 2 \mathrm{MS}$ medium showed that the reduction by $50 \%$ of inorganic salts, including nitrate and ammonium concentrations, in MS medium leads to an increase in biomass production of $D$. moldavica hairy roots. However, their fresh and dry weights were much lower than in WP or $1 / 2 \mathrm{WP}$ media (Table 1). The concentration of nitrate $(9.8 \mathrm{mM})$ and ammonium $(5.0 \mathrm{mM})$ in WP medium was four times lower than in MS medium, although the ratio between these ions was similar in both types of media (2:1). The type of used medium influenced the fresh to dry weight $(\mathrm{FW} / \mathrm{DW})$ ratio in transformed root cultures of D. moldavica. Park and Kim (1993) have reported that the FW/DW ratio is different for various cultures and its value is related to medium osmolarity. The authors noticed a gradual decrease in the FW/DW ratio in cell cultures of T. rugosum and L. erythorhizon with an increase in the basal salt concentration in MS medium. Similar trends were observed in our study. D. moldavica roots growing in full-strength media (MS, B5) resulted in a lower ratio of FW/DW than in media with the reduced to half concentration of inorganic salts $(1 / 2 \mathrm{MS}, 1 / 2 \mathrm{~B} 5)$. The lowest FW/DW ratio was reached in roots cultured in MS medium. In this case, the FW/DW ratio was almost two times

Table 1 Effect of medium composition on growth and rosmarinic acid content of D. moldavica hairy roots cultured under $16 \mathrm{~h}$ photoperiod or in dark for a period of 35 days

\begin{tabular}{|c|c|c|c|c|}
\hline Medium & Cultivation & Fresh wt (g flask $^{-1}$ ) & Dry wt $\left(\mathrm{g} \mathrm{flask}^{-1}\right)$ & RA content $\left(\mathrm{mg} \mathrm{g}^{-1}\right.$ dry wt) \\
\hline \multirow[t]{2}{*}{ MS } & Photoperiod & $0.47 \pm 0.05^{\mathrm{h}}$ & $0.16 \pm 0.05^{\mathrm{f}}$ & $25.96 \pm 0.14^{\mathrm{cd}}$ \\
\hline & Darkness & $0.67 \pm 0.08^{\mathrm{h}}$ & $0.17 \pm 0.03^{\mathrm{f}}$ & $22.75 \pm 0.18^{\mathrm{d}}$ \\
\hline \multirow[t]{2}{*}{$1 / 2 \mathrm{MS}$} & Photoperiod & $1.50 \pm 0.05^{\mathrm{f}}$ & $0.29 \pm 0.05^{\mathrm{de}}$ & $30.34 \pm 0.21^{\mathrm{c}}$ \\
\hline & Darkness & $1.51 \pm 0.05^{\mathrm{f}}$ & $0.33 \pm 0.05^{\mathrm{de}}$ & $28.44 \pm 0.20^{\mathrm{cd}}$ \\
\hline \multirow[t]{2}{*}{ B5 } & Photoperiod & $1.42 \pm 0.24^{\mathrm{fg}}$ & $0.26 \pm 0.04^{\mathrm{de}}$ & $27.76 \pm 0.14^{\mathrm{cd}}$ \\
\hline & Darkness & $1.17 \pm 0.1^{\mathrm{g}}$ & $0.19 \pm 0.01^{\mathrm{f}}$ & $4.47 \pm 0.19^{g}$ \\
\hline \multirow[t]{2}{*}{$1 / 2 \mathrm{~B} 5$} & Photoperiod & $2.55 \pm 0.23^{\mathrm{ed}}$ & $0.30 \pm 0.03^{\mathrm{e}}$ & $78.05 \pm 0.20^{\mathrm{a}}$ \\
\hline & Darkness & $2.21 \pm 0.15^{\mathrm{e}}$ & $0.21 \pm 0.02^{\mathrm{d}}$ & $52.41 \pm 0.13^{\mathrm{b}}$ \\
\hline \multirow[t]{2}{*}{ WP } & Photoperiod & $7.23 \pm 0.47^{\mathrm{a}}$ & $0.89 \pm 0.05^{\mathrm{e}}$ & $11.92 \pm 0.18^{\mathrm{ef}}$ \\
\hline & Darkness & $4.62 \pm 0.14^{\mathrm{b}}$ & $0.61 \pm 0.02^{\mathrm{b}}$ & $10.90 \pm 0.15^{\mathrm{f}}$ \\
\hline \multirow[t]{2}{*}{$1 / 2 \mathrm{WP}$} & Photoperiod & $3.25 \pm 0.27^{\mathrm{c}}$ & $0.51 \pm 0.07^{\mathrm{c}}$ & $16.76 \pm 0.12^{\mathrm{e}}$ \\
\hline & Darkness & $2.90 \pm 0.23^{\mathrm{cd}}$ & $0.49 \pm 0.09^{\mathrm{c}}$ & $15.23 \pm 0.14^{\mathrm{ef}}$ \\
\hline
\end{tabular}

Each value represented mean of three replicates \pm SE. Means with the same letters within column are not significantly different at $p \leq 0.05$ according to the Mann-Whitney $U$ test 
lower than the ratio in $1 / 2 \mathrm{MS}$ medium. According to Park and Kim (1993), the ratio has been just used as an index of cell size. Our data may suggest that relatively lower FW/DW ratio may result in a decrease in cell volume. However, it has not been experimentally determined.

Identification of RA was based on UPLC retention times and LC-ESI-MS/MS analysis. The UPLC analysis confirmed the presence of RA in tested samples according to the same retention time of $3.8 \mathrm{~min}$ as standard (Fig. 1). The structural elucidation of RA was achieved by negative ionization LC-ESI-MS/MS. MS data for RA showed a prominent $[\mathrm{M}-\mathrm{H}]^{-}$product ion at $\mathrm{m} / \mathrm{z} 358.8$, which was assigned to the molecular ion (MW 360). The fragmentation pattern with prominent peaks at $\mathrm{m} / \mathrm{z}$ 197.0, 179.2, $160.9,134.9$ in the negative ion spectrum was consistent with that reported in the literature (Nuengchamong et al. 2011). The fragmentations at $\mathrm{m} / \mathrm{z} 179.2$ and $\mathrm{m} / \mathrm{z}, 197.0$ indicate the presence of a caffeic acid moiety and 2-hydroxy derivative of hydrocaffeic acid, respectively. This fragmentation pattern corresponded well to the two components of rosmarinic acid as 3,4-dihydroxycinnamic acid (R)-1-carboxy-2-(3,4-dihydroxyphenyl)ethyl ester. The fragmentation at $\mathrm{m} / \mathrm{z} 160.9$ shows the dehydrated ion fragments of these two constituents $\left[197-2 \mathrm{H}_{2} \mathrm{O}\right]^{-}$and $\left[179-\mathrm{H}_{2} \mathrm{O}\right]^{-}$. The information from mass spectra as well as the comparison with the standard compound led to an unambiguous identification of RA in the studied of D. moldavica hairy roots.

Different compositions of basal salts and their concentrations in the culture media affected the RA content in hairy roots of D. moldavica (Table 1). The highest amount of RA (78 $\mathrm{mg} \mathrm{g}^{-1}$ dry wt) was produced in transformed roots growing in $1 / 2 \mathrm{~B} 5$ medium under a $16 \mathrm{~h}$ photoperiod. The level was almost threefold higher than RA content of

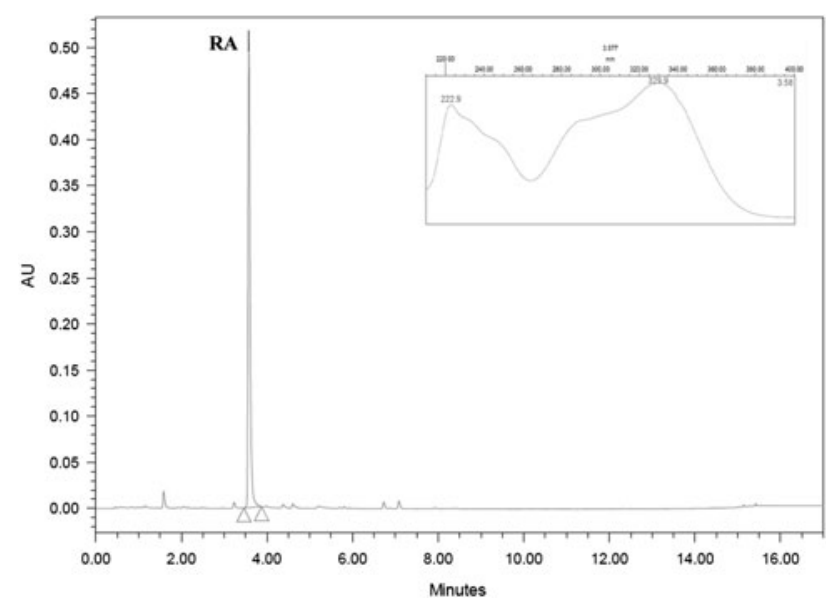

Fig. 1 UPLC chromatogram of methanolic extract from hairy roots of D. moldavica and UV spectrum of rosmarinic acid hairy roots cultured in full-strength B5 medium under the same light conditions. Taking the biomass measurements of hairy roots into account, the RA production expressed per liter of culture was $295.5 \mathrm{mg} \mathrm{L}^{-1}$ in $1 / 2 \mathrm{~B} 5$ medium versus $90.5 \mathrm{mg} \mathrm{L}^{-1}$ in $\mathrm{B} 5$ medium. The lowest amount of RA ranged between 12 and $17 \mathrm{mg} \mathrm{g}^{-1}$ dry wt and was found in transformed roots of D. moldavica grown in media comprising WP salts (WP and $1 / 2 \mathrm{WP}$ ), although the root biomass accumulation was high in the media. However, even if we take into account better growth of roots in WP and $1 / 2 \mathrm{WP}$ media, the production of RA (in $\mathrm{mg} \mathrm{L}^{-1}$ ) in the media was over twice lower than in $1 / 2 \mathrm{~B} 5$. The results suggest that media favoring the growth of cultured roots were less effective in stimulating RA content. It is often noted in in vitro plant cultures that the production of secondary metabolites is separated from growth $(\mathrm{Li}$ et al. 2005; Bauer et al. 2011). A reverse relation between the growth and RA content was observed by Kim et al. (2001) in suspension culture of Agastache rugosa and by Françoise et al. (2007) in callus culture of Zataria multiflora. Generally, hairy roots of $D$. moldavica growing under light conditions ( $16 \mathrm{~h}$ light at intensity of $40 \mu \mathrm{m} \mathrm{m}^{-2} \mathrm{~s}^{-1}$ ) accumulate more RA as compared to RA accumulated in dark grown cultures, but in most cases, the increase was less than $15 \%$. Statistically significant $(p \leq 0.05)$ differences were only found in the roots cultured in B5 and $1 / 2$ B5 media (Table 1 ). Komali and Shetty (1998) have reported that the light had no effect on RA level in Rosmarinus officinalis callus culture, which was obtained after A. rhizogenes infection and maintained on hormone-free MS medium. Similar results were obtained by Grzegorczyk et al. (2006) in hairy roots of Salvia offcinalis cultured under the light and dark conditions. Among seven $S$. officinalis transformed root clones tested, only one produced significantly higher level of RA growing in WP medium in the presence of light.

The work described here is the first report demonstrating a substantial amount of RA accumulation in hairy roots culture of $D$. moldavica. The comparative analysis of RA accumulation in normal roots from 6-month-old plants of D. moldavica showed that the level of RA $\left(7.9 \mathrm{mg} \mathrm{g}^{-1}\right.$ dry $w t$ ) in the roots was only $1 / 10$ of that in transformed roots, when they were cultured under optimized conditions, i.e. in $1 / 2 \mathrm{~B} 5$ liquid medium in the presence of periodic light. There have been several reports on RA production in roots transformed by A. rhizogenes at higher levels than in roots of field-grown plants. For example, $50 \mathrm{mg}$ RA per gram of dry weight was found in hairy roots of Coleus blumei, while the roots of parent plant produced RA at the level of $17 \mathrm{mg} \mathrm{g}^{-1}$ dry weight (Bauer et al. 2009). In hairy roots cultures of Hyssopus officinalis, the production of RA increased about $60 \%$ compared to normal roots of the plant species (Kochan et al. 1999). 
Table 2 Antioxidant capacities of methanolic extracts of D. moldavica roots measured by reducing power (expressed as grams of ascorbic acid equivalents per gram of dry extract) in phosphomolybdenum assay and DPPH free radical scavenging activity expressed as $\mathrm{EC}_{50}\left(\mu \mathrm{g} \mathrm{mL}^{-1}\right.$ )

\begin{tabular}{llc}
\hline Plant material & Reducing power $^{\mathrm{a}}\left(\mathrm{g} \mathrm{AAE} \mathrm{g} \mathrm{extract}{ }^{-1}\right)$ & DPPH scavenging $^{\mathrm{b}} \mathrm{EC}_{50}\left(\mu \mathrm{ml}^{-1}\right)$ \\
\hline HR-1 & $0.307 \pm 0.02^{\mathrm{b}}$ & $25.0 \pm 0.08^{\mathrm{e}}$ \\
HR-2 & $0.286 \pm 0.01^{\mathrm{c}}$ & $26.56 \pm 0.04^{\mathrm{d}}$ \\
HR-3 & $0.268 \pm 0.05^{\mathrm{d}}$ & $43.21 \pm 0.06^{\mathrm{b}}$ \\
HR-4 & $0.228 \pm 0.01^{\mathrm{e}}$ & $44.98 \pm 0.45^{\mathrm{a}}$ \\
RF & $0.210 \pm 0.01^{\mathrm{f}}$ & $44.62 \pm 0.05^{\mathrm{a}}$ \\
BHT & $0.224 \pm 0.02^{\mathrm{e}}$ & $29.40 \pm 0.30^{\mathrm{c}}$ \\
$\alpha$-Tocopherol & $0.624 \pm 0.01^{\mathrm{a}}$ & $23.6 \pm 0.05^{\mathrm{f}}$ \\
\hline
\end{tabular}

Each value is the mean of three replicates \pm SE. Means with the same letters within column are not significantly different at $p \leq 0.05$ according to the Mann-Whitney $U$ test

$H R-1$ hairy roots grown in $1 / 2 \mathrm{~B} 5$ medium, under photoperiod, $H R-2$ hairy roots grown in $1 / 2 \mathrm{~B} 5$ medium in darkness, $H R-3$ hairy roots grown in WP medium under photoperiod, $H R-4$ hairy roots grown in WP medium in darkness, $R F$ roots of filed-grown plants

${ }^{\text {a }}$ Extract concentration: $100 \mu \mathrm{g} \mathrm{ml}^{-1}$; temperature $90{ }^{\circ} \mathrm{C}$

b The concentration of sample showing $50 \%$ of maximal DPPH radical scavenging activity

An antioxidant potential of methanolic extracts of D. moldavica hairy roots was determined using the DPPH free radical scavenging and reducing metal ions in phosphomolybdenum assays. Hairy roots grown in $1 / 2 \mathrm{~B} 5$ and WP liquid media under periodic light ( $16 \mathrm{~h}$ light $/ 8 \mathrm{~h}$ dark) and in darkness were chosen to evaluate antioxidant properties (Table 2). They were different in respect to growth and accumulation of RA (Table 1). For comparison, antioxidant properties of methanolic extract of roots of $D$. moldavica intact plants were measured. The total content of phenolic compounds in extracts of the roots, expressed as milligrams of gallic acid per gram of extract was also determined. The content ranged from $105 \mathrm{mg} \mathrm{GAE} \mathrm{g}^{-1}$ of the extract for roots of intact plants to $217 \mathrm{mg} \mathrm{GAE} \mathrm{g}^{-1}$ of the extract for hairy roots cultured in $1 / 2 \mathrm{~B} 5$ medium under

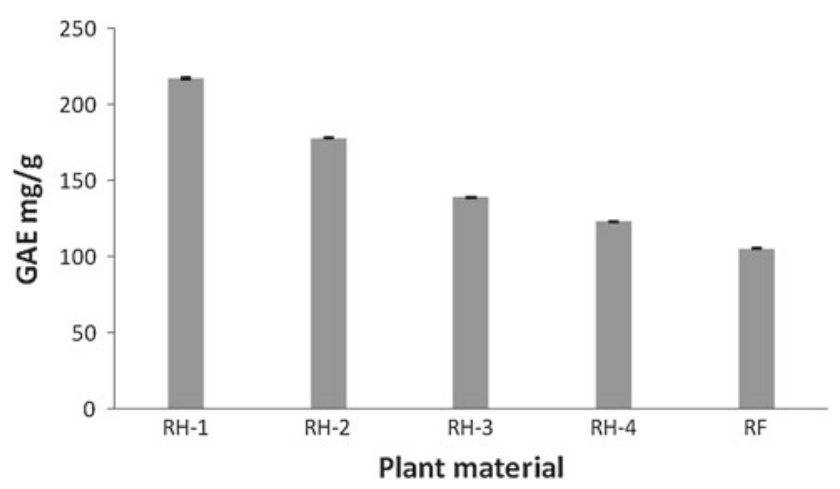

Fig. 2 Total content of phenolics in methanolic extracts of hairy roots and roots of intact plants of D. moldavica, expressed as gallic acid equivalents in $\mathrm{mg}$ per $\mathrm{g}$ of extract. $H R-1$ hairy roots grown in $1 / 2 \mathrm{~B} 5$ medium, under photoperiod, $H R-2$ hairy roots grown in $1 / 2 \mathrm{~B} 5$ medium in darkness, $H R-3$ hairy roots grown in WP medium under photoperiod, $H R-4$ hairy roots grown in WP medium in darkness, $R F$ roots of filed-grown plants. Values are means of three replicates $\pm \mathrm{SE}$ photoperiod (Fig. 2). From $\mathrm{EC}_{50}$ values, it can be seen that methanolic extract of hairy roots grown in $1 / 2 \mathrm{~B} 5$ medium under a photoperiod was the most potent scavenger $\left(\mathrm{EC}_{50}=25.0 \mu \mathrm{g} \mathrm{mL}^{-1}\right)$. Its antioxidant activities were similar to recognized antioxidant BHT and $\alpha$-tocopherol (Table 2). This is in agreement with a higher amount of total phenolic compounds and RA content in the roots compared to other roots tested (Table 1; Fig. 2). The lowest scavenging activity with $\mathrm{EC}_{50}$ value of about $45 \mathrm{mg} \mathrm{mL}^{-1}$ was exhibited by the extract of hairy roots cultured in WP medium in the dark and roots of fieldgrown plants of D. moldavica.

In Table 2, the difference between methanolic extracts in their reducing ability towards molybdenum ions was also shown. The formation of green phosphomolybdenum complex was measured by the intensity of absorbance of extracts at the concentration of $100 \mu \mathrm{g} \mathrm{mL}^{-1}$ at $90{ }^{\circ} \mathrm{C}$. Similar as in DPPH assay, extracts from hairy roots were stronger reducers of metal ions than extract of roots of D. moldavica intact plants. The differences were significant at $p \leq 0.05$. Among the extracts tested, the greatest reducing power exhibited HR-1 extract (from hairy roots grown in $1 / 2 \mathrm{~B} 5$ medium under a photoperiod), and HR-2 extract (hairy roots grown in $1 / 2 \mathrm{~B} 5$ medium in the dark). On the basis of the correlation coefficient values calculated for the antioxidant assays versus total phenolic and RA contents, it can be suggested that both the radical scavenging ability and the reducing power of the analyzed extracts were well correlated with the total amount of phenolic compounds $\left(r^{2}=0.87\right.$ and 0.98 , respectively) and less with RA content $\left(r^{2}=0.55\right.$ and 0.82 , respectively) (Fig. 3). It is known that RA plays a major role in determining antioxidant capacity of various species of Lamiaceae family (subfamily Nepetoidae). This activity is mainly due to RA redox properties, which play an important role 


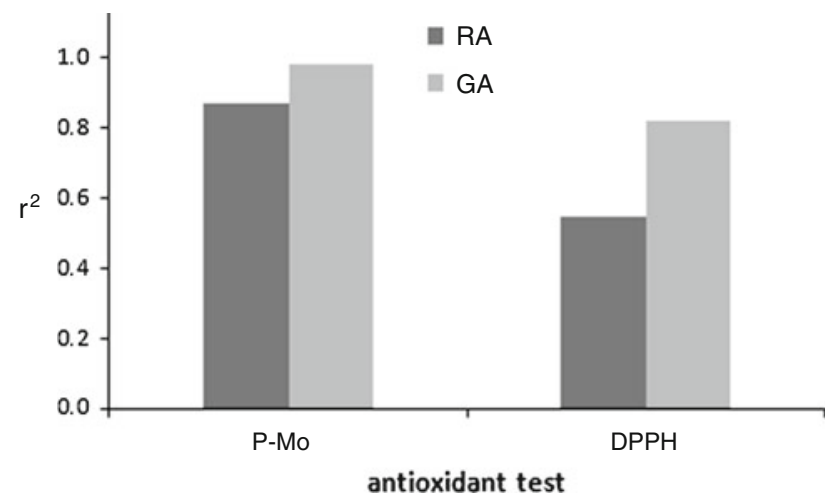

Fig. 3 Comparison of correlation coefficients $\left(r^{2}\right)$ between antioxidant assays and total phenolic (milligram of gallic acid equivalents - GAE per gram of extract) or RA ( $\mathrm{mg} \mathrm{g}^{-1}$ dry wt) contents in methanolic extract. $D P P H$ free radical scavenging assay, $P-M o$ phosphomolybdenum assay

in adsorbing and neutralizing free radicals, quenching singlet and triplet oxygen or decomposing peroxides (Furtado et al. 2008; Krzyżanowska et al. 2011). The ability is mainly based on the presence of four hydroxyl groups in orthoposition in the aromatic rings of RA. In the literature, there are also reports on the presence of additional phenolic compounds in D. moldavica plants, which, besides RA, can be responsible for the observed antioxidant activity. These include caffeic acid, chlorogenic acid (Kakasy et al. 2006), phenylpropanoids and flavonoids (Sultan et al. 2008). To identify the compounds in hairy roots of D. moldavica, further phytochemical analyses are needed.

In conclusion, our results indicate that RA production in hairy roots of D. moldavica was strongly affected by a type of culture media. For optimum production, the cultures should be grown in half-strength Gamborg's B5 liquid medium under periodic light conditions $(16 \mathrm{~h}$ light $/ 8 \mathrm{~h}$ dark). Thus, it is possible to generate a transformed root line with significantly higher content of RA than that of roots of field-grown plants of D. moldavica. The increase in the content of RA and the total amount of Folin-Ciocalteu relative compounds probably contributes to superior antioxidant activity of hairy roots of $D$. moldavica.

Author contribution I. Weremczuk-Jeżyna obtained transformed roots of D. moldavica, cultured them in flask in various media, studied the biomass changes, perpetrated samples for UPLC and LC-MS/MS analyses and described the results. B. Frydrych performed UPLC analysis. I. Grzegorczyk-Karolak performed antioxidant assays. A. Królicka performed PCR analyses and description of obtained results. H. Wysokińska was responsible for verification of the paper.

Acknowledgments The authors would like to thank dr M. Wielanek for LC-MS/MS analysis. This research was financially supported by the grant of Medical University of Lodz (502-13-768).
Open Access This article is distributed under the terms of the Creative Commons Attribution License which permits any use, distribution, and reproduction in any medium, provided the original author(s) and the source are credited.

\section{References}

Bais HP, Walker TS, Schweizer HP, Vivanco JM (2002) Root specific elicitation and antimicrobial activity of rosmarinic acid in hairy root cultures of Ocimum basilicum. Plant Physiol Biochem 40:983-995. doi:10.1016/s0981-9428(02)1460-2

Bauer N, Leljak-Levanic D, Jelaska S (2004) Rosmarinic acid synthesis in transformed callus culture of Coleus blumei Benth. Z Naturforsch 59c:554-560

Bauer N, Kiseljak D, Jelaska S (2009) The effect of yeast extract and methyl jasmonate on rosmarinic acid accumulation in Coleus blumei hairy roots. Biol Plantarum 53:650-656. doi:10.1007/ s10535-009-0147-3

Bauer N, Fulgosi H, Jelasaka S (2011) Overexpression of phenylalanine ammonia-lyase in transgenic roots of Coleus blumei alerts growth and rosmarinic acid synthesis. Food Technol Biotech 49:24-31

Bekesiova I, Nap JP, Mlynarova L (1999) Isolation of high quality DNA and RNA from leaves of the carnivorous plant Drosera rotundifolia. Plant Mol Biol Rep 17:269-277. doi:10.1023/ A: 1007627509824

Bensaddek L, Gillet F, Nava-Saucedo JE, Fliniaux MA (2001) The effect of nitrate and ammonium concentrations on growth and alkaloid accumulation of Atropa belladonna hairy roots. J Biotechnol 85:35-40. doi:10.1016/S0168-1656(00)00372-2

Brand-Williams W, Cuvelier ME, Berset C (1995) Use of a free radical methods evaluate antioxidant activity. Lebensm Wiss Technol 28:25-30. doi:10.1016/S0023-6438(95)80008-5

Chun SS, Vattem DA, Lin YT, Schetty K (2005) Phenolic antioxidant from clonal oregano (Origanum vulgare) with antimicrobial activity against Helicobacter pylori. Process Biochem 40: 809-816. doi:10.1016/j.procbio.2004.02018

Danesh YR, Galtapeh EM, Alizadeh A (2006) Study on the growth patterns of transformed carrot hairy roots in on optimized system. J Agric Technol 2:89-97

Dastmalchi K, Dorman HJD, Kosar M, Hiltunen R (2007a) Chemical composition and in vitro antioxidant evaluation of water-soluble Moldavian balm (Dracocephalum moldavica L.) extract. Food Sci Technol 40:239-248. doi:10.1016/j.lwt.2005.09.019

Dastmalchi K, Dorman HJD, Laakso I, Hiltunen R (2007b) Chemical composition and antioxidative activity of evaluation Moldavian balm (Dracocephalum moldavica L.) extracts. Food Sci Technol 40:1655-1663. doi:10.1016/j.lwt.2006.11.013

Françoise B, Hossein S, Halimeh H, Zahra NF (2007) Growth optimization of Zataria multiflora Boiss. tissue cultures and rosmarinic acid production improvement. Pak J Biol Sci 10:3395-3399. doi:10.3923/pjbs.2007.33395.3399

Furtado MA, Almeida LCF, Furtado RA, Cuntra WR, Tavers DC (2008) Antimutagenicity of rosmarinic acid in swiss mice evaluated by the micronucleus assay. Mutat Res Genet Toxicol Environ 657:150-154. doi:10.1016/j.mrgentox.2008.09.003

Gamborg OL, Miller RA, Ojima K (1968) Nutrient requirements of suspension cultures of soybean root cells. Exp Cell Res 50:151-158. doi:10.1016/0014-4827(68)90403-5

Georgiev M, Kuzeva S, Pavlov A, Kovackeva E, Ilieva M (2006) Enhanced rosmarinic acid production by Lavandula vera MM cell suspension culture through elicitation with vanadyl sulfate. Z Naturforsch 61c:241-244 
Ghanndi A, Sajjadi SE, Abedi D, Yousefi J, Daraei-Ardekami R (2004) The in vitro activity of seven Iranian plants of the Lamiaceae family against Helicobacter pylori. Niger J Nat Prod Med 8:40-42

Giri A, Narasu ML (2000) Transgenic hairy root recent trends and applications. Biotechnol Adv 18:1-22. doi:10.1016/S0734-9750 (99)00016-6

Grzegorczyk I, Królicka A, Wysokińska H (2006) Establishment of Salvia officinalis hairy root cultures for the production of rosmarinic acid. Z Naturforsch 61C:351-356

Janicsàk G, Màthè I, Miklòssy-Vàri V, Blunden G (1999) Comparative studies of the rosmarinic and caffeic acid contents of Lamiceae species. Biochem Syst Ecol 27:733-738. doi:10.1016/ jbse.2005.12.004

Kakasy AF, Füzfai Z, Kursinszki L, Malnàr-Parl I, Lemberkovics E (2006) Analysis of non-volatile constituents in Dracocephalum species by HPLC and GC-MS. Chromatographia 63:17-23. doi: 10.1365/s10337-006-0741-x

Kim HK, Oh SR, Lee HK, Huh H (2001) Benzothidiazole enhances the elicitation of rosmarinic acid production in a suspension culture of Agastache rugosa O. Kuntze. Biotechnol Lett 23:55-60. doi:10.1023/A:1026738409671

Kochan E, Wysokińska H, Chmiel A, Grabias B (1999) Rosmarinic acid and other phenolic acids in hairy roots of Hyssopus officinalis. Z. Naturforsh 54c:11-16

Komali AS, Schetty K (1998) Comparison of the growth pattern and rosmarinic acid production in rosemary (Rosmarinus officinalis) shoots and genetically transformed callus cultures. Food Biotechnol 12:27-41. doi:10.1080/08905439809549941

Krzyżanowska J, Czubacka A, Pecio Ł, Przybyś M, Doroszewska T, Stochmal A, Oleszek W (2011) The effect of jasmonic acid and methyl jasmonate on rosmarinic acid production in Mentha $\times$ piperita cell suspension cultures. Plant Cell Tissue Organ Cult 108:73-81. doi:10.1007/s11240-011-0014-8

Lamien-Meda A, Nell M, Lohwaner U, Bömer A, Franz C, Novak J (2010) Investigation on antioxidant and rosmarinic acid variation in the sage collection of the genebank gatersleben. J Agric Food Chem 58:3813-3819. doi:10.1021/jf903993f

Li W, Koike K, Asada Y, Yoshikawa T, Nikaido T (2005) Rosmarinic acid production by Coleus forskohlii hairy roots. Plant Cell Tissue Organ Cult 80:151-155. doi:10.1007/s11240-004-9541-x

Lloyd G, Mc Cown B (1981) Commercially feasible micropropagation of mountain laurel, Kalmia latifolia by use of shoot tip culture. Int Plant Prop Soc 30:421-427

Ly TN, Shimoyama M, Yamamuchi R (2006) Isolation and characterization of rosmarinic acid oligomers in Celastrus hindssi Benth leaves and their antioxidative activity. J Agric Food Chem 54:3786-3793. doi:10.1021/jf052743f

Murashige T, Skoog F (1962) A revised medium for rapid growth and bioassay with tobacco tissue culture. Physiol Plantarum 15:473-497. doi:10.1111/ppl.1962.15.issue-3/issutoc
Nuengchamong N, Krittasilp K, Ingkaniaran K (2011) Characterization of phenolic antioxidants in aqueous extract of Orthosiphon grandiflorus tea by LC-ESI-MS/MS coupled to DPPH assay. Food Chem 127:1287-1293. doi:10.1016/j.foodchem.2011.01. 085

Park S, Kim D (1993) Significance of fresh weight to dry cell weight ratio in plant cell suspension. Biotechnol Tech 9:627-630. doi: 10.1007/BF00151859

Park SU, Uddin MR, Xu H, Kim YK, Lee SY (2008) Biotechnological applications for rosmarinic acid production in plant. Afr J Biotechnol 7:4959-4965. doi:10.5897/AJB08.088

Popova OI, Nikitina AS, Markova OM (2008) Studies of iridoids from Dracocephalum moldavica cultivated in the Stavropol region. Pharm Chem J 42:351-353. doi:10.1007/s11094-00801239

Povilaitytè V, Cuvelier ME, Berset C (2001) Antioxidant properties of moldavian dragonhead (Dracocephalum moldavica L.). J Food Lipids 8:45-64. doi:10.1111/j.1745-4522.2001t600183x

Prieto P, Pineda M, Aquilar M (1999) Spectrophotomeric quantitation of antioxidant capacity through the formation of phosphomolybdenum complex; specific application to the determination of vitamin E. Anal Biochem 269:337-341. doi:10.1006/abio. 1999.4019

Richter G (1993) Mètabolisme des vègètaux physiologie et biochimie. Presses Polytechniques et Universitaires Romandes, Lousanne, pp. 341-344

Sanchez-Medina A, Ethridge CJ, Hawkes GL, Hylands PJ, Pendry BA, Hughes MJ, Corcoran O (2007) Comparison of rosmarinic acid content in commercial tinctures produced from fresh and dried limon balm (Melissa officinalis). J Pharm Sci 10:455-463

Singleton V, Rossi JA (1965) Colorimetry of total phenolics with phosphomolybdic-phosphotungstic acid reagents. Am J Enol Viticult 16:144-158

Sultan A, Bahang H, Aisa HA, Eshbakova KA (2008) Flavonoids from Dracocephalum moldavica. Chem Nat Comp 44:366-367. doi:10.1007/s10600-008-9065-4

Tewtrakul S, Miyashio H, Nakamura N, Hattori M, Kawahata T, Otaku T, Yoshinaga T, Fujiwara T, Supavita T, Yuenyongsawad S, Rattanasuwon P, Dej-Adisai S (2003) HIV-I integrase inhibitory substances from Coleus paroifolius. Phytotherapy Res 17:232-239. doi:10.1002/pfr.1111

Vervliet G, Holsters M, Teuchy H, Van Montagu M, Shell J (1975) Characterization of different plaque-forming and defective temperate phages in Agrobacterium strains. J Gen Virol 26: 33-48. doi:10.1099/0022-1317-26-1-49

Wu CH-H, Dewir YH, Hahn E-J, Paek KY (2006) Optimization of culturing conditions for the production of biomass and phenolic from adventitious roots of Echinacea angustifola. J Plant Biol 49:193-199. doi:10.1007/BF03030532 